\title{
The Inhibitory Effect of Curcumin on Hypoxia Inducer Factors (HIFS) as a Regulatory Factor in the Growth of Tumor Cells in Breast Cancer Stem-Like Cells
}

\author{
Authors \\ Mehrnaz Asadi Sarighieh ${ }^{1}$, Vahideh Montazeri ${ }^{1}$, Amir Shadboorestan², Mohammad Hossein Ghahremani ${ }^{1}$, \\ Seyed Nasser Ostad 1
}

\begin{abstract}
Affiliations
1 Department of Pharmacology and Toxicology, Faculty of Pharmacy, Tehran University of Medical Sciences, Tehran, Iran
\end{abstract}

2 Department of Toxicology, Faculty of Medical Sciences, Tarbiat Modares University, Tehran, Iran

Key words

anticancer drugs, apoptosis, toxicology

received 27.04.2020

accepted 15.06.2020

published online $\quad 23.09 .2020$

Bibliography

Drug Res 2020; 70: 512-518

DOI 10.1055/a-1201-2602

ISSN 2194-9379

(c) 2020. Thieme. All rights reserved.

Georg Thieme Verlag KG, Rüdigerstraße 14,

70469 Stuttgart, Germany

(c) Georg Thieme Verlag KG Stuttgart · New York

ISSN 2194-9379

\section{Correspondence}

Prof. Seyed Nasser Ostad

Department of Toxicology and Pharmacology, Faculty of Pharmacy, Tehran University of Medical Sciences,

16 Azad St.,

Tehran 1417614411

Iran

Tel.: + 9866959105, Fax: + 9866959105

ostadnas@tums.ac.ir

\begin{abstract}
Hypoxia in the microenvironment is related to chemotherapy resistance, tumor progression, and metastasis. Curcumin, as a phenolic compound extracted from the turmeric, has been used as an anti-cancer agent with low toxicity in recent years. Since curcumin has inhibitory activities against hypoxia-inducible factors (HIFs) in several cancers, this study was conducted to examine the effect of curcumin on MCF-7 cells and cancer stem-like cells (CS-LCs) under hypoxic and normoxic conditions. CS-LCs were isolated from MCF-7 cells using the magnet activated cell sorting (MACS) method based on $\mathrm{CD}_{44}{ }^{+} / \mathrm{CD}_{24}{ }^{-}$ surface markers. The effects of curcumin on the viability of MCF-7 cells and CS-LCs were examined in hypoxic and normoxic conditions using the MTT test. The effects of curcumin on apoptosis and cell cycle of CS-LCs and MCF-7 cells were analyzed using flow cytometry. Moreover, the inhibitory effects of curcumin on the levels of HIF- 1 and HIF-2 $\alpha$ protein in CS-LCS were investigated using the western blot method. Early apoptosis occurred in CSC-LCs more than MCF-7 cells under hypoxic conditions. Flow cytometry assay showed that curcumin caused cell cycle arrest of CSC-LCs and MCF-7 at the G2/M phase under hypoxic conditions while under normoxic conditions, arrest occurred at the $\mathrm{G} 0 / \mathrm{G} 1$ phase in MCF-7 cells and at $\mathrm{S}$ and $\mathrm{G} 2 / \mathrm{M}$ phases in CS-LCs. Based on the results, the curcumin inhibited the expression of HIF-1 by degrading ARNT in CS-LCs. In conclusion, curcumin has inhibitory effects on MCF7 cells and CS- LCs and thus may be used as an antitumor agent.
\end{abstract}

\section{Introduction}

Breast cancer is the most common malignancy and the second cause of cancer death among women in the worldwide [1]. About 1 in 8 women will have invasive breast cancer at some point in their lives in the United States [2]. There are various treatments for breast cancer such as surgery, chemotherapy, and immunotherapy $[3,4]$. It has been proven that early diagnosis could help to improve the response to treatment and increase the survival rate in patients [4]. Nevertheless, standard treatment fails in patients with hormone resistant breast cancer in whom the tumor eventually relapses. Several studies found that the small subpopulations of tumor cells known as cancer stem cells (CSCs) had a principal role in tumor progression and chemotherapy resistance; these cells have self-renewal capacity and differentiate into other tumor cells [5, 6]. How- 
ever, CSCs escape from chemotherapy due to their quiescent state; in addition, they express high levels of drug efflux transporters and other genes that contribute to drug resistance. Therefore, it is necessary to investigate new therapeutic agents that can eliminate the CSCs $[7,8]$. Previous studies found that cancer stem-like cells (CSLCs) could be identified and isolated from tumors based on cell surface markers. For instance, CSC markers in breast cancer cell lines are identified by high $\mathrm{CD}_{44}$ and low $\mathrm{CD}_{24}$ expression $\left(\mathrm{CD}_{44}{ }^{+} / \mathrm{CD}_{24}{ }^{-/ \text {low }}\right)$ $[9,10]$.

As a result of structural abnormalities of microvessels during the progression of the solid tumors, blood vessels cannot supply sufficient oxygen to the neoplastic and stromal cells; therefore, hypoxia conditions occur in the tumor microenvironment. Hypoxia induces the activity of two hypoxia- inducible factors (HIFs), HIF1 and HIF2 $\alpha$. HIF1 is a complex of HIF1 $\alpha$ and HIF1 $\beta$ subunits or aryl hydrocarbon receptor nuclear translocator (ARNT) that upregulates under hypoxic conditions. Additional studies have shown that HIF1 activates several genes that have a pivotal role in cancer progression. Moreover, it has been established that the activity of HIF- $2 \alpha$ results in the progression of several malignancies such as clear cell renal cell carcinoma, lung carcinoma, and neuroblastoma [11]. Therefore, expression of HIF target genes enhances tumor progression and metastasis, resulting in a substantial increase in patient mortality. Accordingly, HIF inhibitors have been considerate as anti-cancer drugs. They are able to inhibit the expression or function of HIF1 $\alpha$ and HIF2 [12].

Curcumin ((1E,6E)-1,7-bis (4-hydroxy- 3-methoxyphenyl) -1,6heptadiene-3,5-dione) is a lipophilic component extracted from the rhizomes of Curcuma longa. In traditional Asian medicine, turmeric is routinely used for treatment of several diseases such as hepatic diseases and anorexia. Some clinical studies reported that curcumin has antitumor and antioxidant effects [13].

In this study, CS-LCs were identified and isolated from breast MCF-7 cells based on surface markers $C D_{44}{ }^{+} / C D_{24}$ low. The inhibitory effect of curcumin on HIF in CS-LCs and parent cells in normoxic and hypoxic conditions were evaluated.

\section{Materials and Methods}

\section{Reagents and Chemicals}

Curcumin (Exir-nano-sina) was prepared using dimethyl sulfoxide (DMSO) and stored at $-20^{\circ} \mathrm{C}$. RPMI-1640, FBS (fetal bovine serum). Penicillin-streptomycin was purchased from Biosera (UckfieldEast Sussex, UK). 3-[4,5-Dimethylthiazol-2-yl]-2,5-diphenyl tetrazolium bromide (MTT) and DMSO were purchased from Sigma (St. Louis, MO). Anti HIF- $1 \alpha$, ARNT and HIF- $2 \alpha$ antibodies were provided by R\&D Systems Inc. Other antibodies (anti- $\mathrm{CD}_{44}$-conjugated microbeads, $C D_{24}$-conjugated biotin and antibiotin- $C_{24}$ ) were purchased from Miltenyi Biotec. Annexin V-FITC and propidium iodide (PI) were purchased from eBioscience (San Diego, CA).

\section{Cell culture}

The MCF-7 (human breast adenocarcinoma) cell line was obtained from the Pasteur Institute Cell Bank of Iran (Tehran, Iran) and cultured in RPMI-1640 medium supplemented with $10 \%$ fetal bovine serum (FBS) and $1 \%$ penicillin/streptomycin. All the cells were incubated in $20 \% \mathrm{O}_{2}$ and $5 \% \mathrm{CO}_{2}$ under normoxic conditions in a normal incubator. For hypoxic conditions, the cells were incubated in different conditions, $1 \% \mathrm{O}_{2}, 5 \% \mathrm{CO}_{2}$, and $\mathrm{N}_{2}$ gasses.

\section{Fluorescence-activated cell sorting analysis (FACS)}

Flow cytometry was used to detect the CS-LCs population of MCF-7 cells. In this method, MCF-7 cells were cultured. After 2 weeks, the cells were trypsinized with trypsin enzyme (BIOWEST) and washed with PBS. Then, the pellets were resuspended and incubated in PBS including $1 \% \mathrm{BSA}$ and antibodies against cell surface markers $\mathrm{CD}_{24^{-}}$ APC (eBioscience, 17024742) and CD $44^{-P E}-$ Cy7 (Abcam, ab82529) for 30 min at $4{ }^{\circ} \mathrm{C}$ in dark conditions.

After the incubation time, the cells were washed with PBS, evaluated using the FACS caliber system (BD Pharmingen), and analyzed using the Flowjo software (Tree Star, Inc., Ashland, OR, USA).

\section{Magnet-Activated Cell Sorting (MACS)}

The $\mathrm{CD}_{44}{ }^{+} / \mathrm{CD}_{24}{ }^{-}$cells as CS-LCs were isolated from MCF- 7 cells using the MACS kit (Miltenyi Biotec, Auburn, CA) according to the manufacturer's protocol. Trypsinized MCF- 7 cells were rinsed with running buffer and labeled directly with $20 \mu \mathrm{MACS}$ anti- $\mathrm{CD}_{44}$-conjugated microbeads at $4{ }^{\circ} \mathrm{C}$ (Miltenyi Biotec). Subsequently, the cells were washed with PBS, $500 \mu \mathrm{l}$ of buffer was added to the cells, and the mixture was placed in the LD column for positive cell separation (Miltenyi Biotec) in the magnetic field (QuadroMACS separator; Miltenyi Biotec). The $\mathrm{CD}_{44}$ - cells were elated and $\mathrm{CD}_{44}{ }^{+}$cells remained in the column. After removing the column from the magnetic field, the $\mathrm{CD}_{44}{ }^{+}$cells retained by the column were washed twice with $1 \mathrm{ml}$ of buffer and cultured.

To isolate the $\mathrm{CD}_{24}$-depleted $\left(\mathrm{CD}_{24}{ }^{-}\right)$cell populations, $8 \times 10^{6}$ $\mathrm{CD}_{44}{ }^{+}$cells were trypsinized. Briefly, $\mathrm{CD}_{44}{ }^{+}$cells were incubated with $40 \mu$ l of running buffer and $10 \mu$ of $C_{24}$ - conjugated biotin (secondary antibody) (Miltenyi Biotec) for $15 \mathrm{~min}$ in the dark at $4^{\circ} \mathrm{C}$. After incubation, the cells were washed with buffer, running buffer was added, and the cells were labeled with $20 \mu \mathrm{l}$ anti-biotin- $\mathrm{CD}_{24}$ microbeads (Miltenyi Biotec) for $15 \mathrm{~min}$ in the dark at $4{ }^{\circ} \mathrm{C}$. After washing with PBS, the cells were re-suspended in $500 \mathrm{ml}$ of buffer and placed in the LD/Depletion column in a magnetic field. Finally, $\mathrm{CD}_{24}$ - depleted $\left(\mathrm{CD}_{24}{ }^{-}\right)$cell populations crossed the column and $\mathrm{CD}_{44}{ }^{+} / \mathrm{CD}_{24}{ }^{-}$cells were isolated from the MCF-7 cells and cultured.

\section{MTT assay}

To determine the effects of curcumin on the viability of MCF-7 cells and CS-LCs, the 3-(4,5-dimethylthiazol-2-yl)-2,5-diphenyl tetrazolium bromide (MTT) assay was used. Cells $\left(1 \times 10^{4}\right.$ per well) were seeded in 96-well plates and incubated overnight. The cells were treated with different concentrations $(5,10,20,40,80$ and $160 \mu \mathrm{M})$ of curcumin and incubated under normoxic and hypoxic conditions for $24 \mathrm{~h}$. Then, after removing the medium, $5 \mathrm{mg} / \mathrm{ml}$ MTT in PBS was added and the cells were incubated at $37^{\circ} \mathrm{C}$ for $4 \mathrm{~h}$. Finally, $100 \mu \mathrm{l}$ dimethylsulfloxide (DMSO) was added to dissolve precipitated Formosan and the absorbance was measured at 570/690 nm using ELISA reader (Anthos, UK). The following formula was used to calculate the cell viability $\left(\mathrm{IC}_{50}\right)$ : 

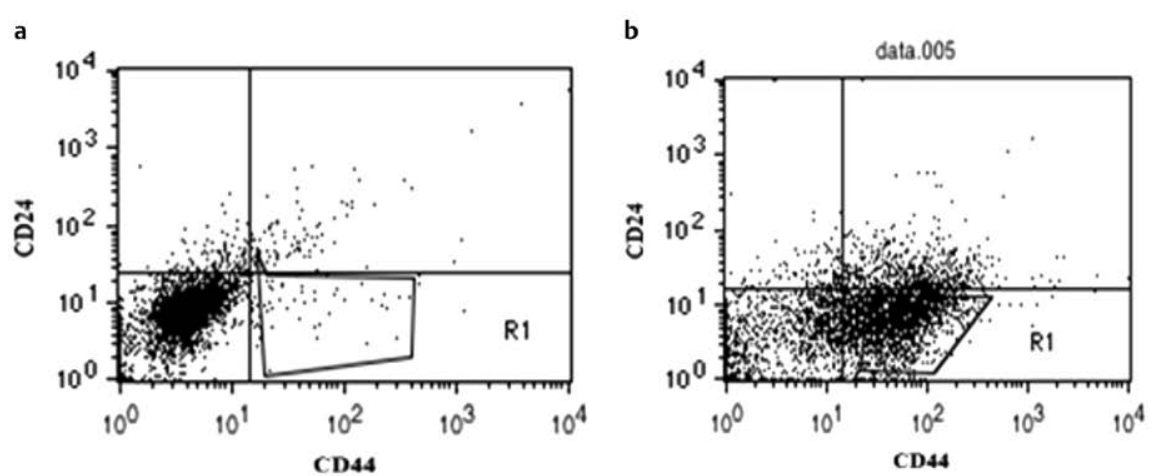

- Fig. 1 Percentage of $\mathrm{CD}_{44}$ and $\mathrm{CD}_{24}$ surface markers in MCF-7 cells. a Flow cytometry analysis showed that $0.78 \%$ of $M C F-7$ cells expressed $\mathrm{CD}_{44}{ }^{+}$I $\mathrm{CD}_{24}{ }^{-}$cell surface markers (R1). $\mathbf{b}$ After isolation using the MACS method, the proportion of cells with $\mathrm{CD}_{44}{ }^{+} / \mathrm{CD}_{24}{ }^{-}$llow phenotype increased to $33.86 \%(R 1)$.

Cell viability $(\%)=[1-(\mathrm{OD}$ of the samples/OD of vehicle treated control) $] \times 100$.

\section{Evaluation of apoptosis by flow cytometry}

For this experiment, $5 \times 10^{5}$ CS-LCs and MCF- 7 cells were cultured in six-well plates and allowed to attach overnight. Then, the cells were treated with $\mathrm{IC}_{50}$ concentration of curcumin for $24 \mathrm{~h}$ under hypoxic and normoxic conditions. After finishing incubation time, the cells were trypsinized, re-suspended in $100 \mu$ l binding buffer containing $10 \mu \mathrm{l}$ Annexin-V-FITC and $5 \mu \mathrm{PI}$, and incubated at room temperature for $15 \mathrm{~min}$ in a dark place. The percent of apoptotic cells was measured via flow cytometry (BD Biosciences, San Jose, (A, USA).

\section{Cell cycle assays}

The CS-LCs and MCF- 7 cells were seeded in six-well plates and treated under the conditions used for apoptosis assay. The cells were harvested, fixed with $2 \mathrm{ml}$ of cold $70 \%$ ethanol in a cold place for $2 \mathrm{~h}$. Then, the cells were suspended in PBS containing $0.05 \%$ Triton X-100 (Sigma), $0.1 \mathrm{mg} / \mathrm{ml}$ DNAse-free RNAse A and $50 \mu \mathrm{g} / \mathrm{ml}$ propidium iodide (Roche) and incubated at room temperature for $45 \mathrm{~min}$. Differences in the cell cycle distribution were determined using the FACS caliber flow cytometer (BD Biosciences, San Jose, CA, USA) and the data were analyzed using the Flowjo software (Tree Star, Inc., Ashland,OR, USA).

\section{Western blot analysis}

The CS-LCs $\left(4 \times 10^{5}\right.$ cells $/ \mathrm{ml} /$ well) were seeded in six-well plates and treated with curcumin under hypoxic and normoxic conditions. After $24 \mathrm{~h}$, the cells were lysed with lysis buffer to extract the total protein [14]. Equal amounts of protein were separated by $10 \%$ SDSPAGE and transferred to a PVDF membrane (Roche, Germany). Subsequently, the membrane was blocked with $5 \%$ non-fat dry milk in TBS-T (0.05\% Tween-20) for two hours at room temperature and blotted for primary antibodies (HIF-1 $\alpha$ : 1:2000; HIF-2 $\alpha$ : 1:2000; ARNT: 1:1000 R\&D Systems and $\beta$-Actin 1:5000 Santa Cruz Biotech) overnight at $4{ }^{\circ} \mathrm{C}$. After washing three times with TBS-T, the membranes were incubated with horseradish peroxidase (HRP)-conju-
- Table $1 \quad \mathrm{IC}_{50}$ values of the Curcumin ( $\mu \mathrm{M}$ ) on CSC-LC and MCF-7 under both normoxic and hypoxic conditions. Results are expressed as mean \pm SD, $\mathrm{N}=9$.

\begin{tabular}{|l|l|l|}
\hline $\mathbf{I C}_{\mathbf{5 0}}$ of Curcumin $(\boldsymbol{\mu M})$ & CSC-LC & MCF-7 cells \\
\hline Normoxia & $24.4 \pm 0.9$ & $30.7 \pm 1.2$ \\
\hline Hypoxia & $19.05 \pm 0.3$ & $15.5 \pm 0.3$ \\
\hline
\end{tabular}

gated secondary antibody at 1: 5000 for 60 min at room temperature and developed using enhanced chemical luminescence detection system (ECL) (Roche, Germany). Bands were analyzed using the Image J software and normalized to corresponding $\beta$-actin band intensity.

\section{Data analysis}

Data were analyzed using the GraphPad Prism version 5.01. The results are presented as mean \pm SD of three independent experiments. Two-way analysis of variance (ANOVA) followed by Tukey post hoc test was utilized for multiple comparisons between the different groups. P values $\leq 0.05$ were considered significant.

\section{Results}

\section{Sorting and identification of $\mathrm{CD}_{44}{ }^{+} / \mathrm{CD}_{24}$ cells from MCF-7 cells}

The CS-LCs were isolated from MCF- 7 cells based on $\mathrm{CD}_{44}{ }^{+} / \mathrm{CD}_{24}{ }^{- \text {llow }}$ phenotype using the MACS method. Fluorescence-activated cell sorter (FACS) was used for characterization of CS-LCs surface markers before and after cell sorting ( $>$ Fig. 1). As shown in $>$ Fig. 1, the evaluation of the proportion of $\mathrm{CD}_{44}{ }^{+} / \mathrm{CD}_{24}$ - llow showed the percentage of CS-LCs increased from $0.78 \%$ to $33.86 \%$.

\section{Inhibitory effect of curcumin on proliferation of CS-LCs and MCF-7 cells}

The results showed that the $50 \%$ inhibitory concentration $\left(\mathrm{IC}_{50}\right)$ of curcumin was $30.7 \pm 1.2$ and $24.4 \pm 0.9 \mu \mathrm{M}$ in MCF-7 cells and CS- 
LCs under normoxic conditions, respectively. The $\mathrm{IC}_{50}$ of curcumin was $15.5 \pm 0.3$ and $19.05 \pm 0.3 \mu \mathrm{M}$ in MCF-7 cells and CS-LCs under hypoxic conditions respectively ( $\triangleright$ Table 1 ), which indicated that curcumin decreased cell viability of MCF-7 cells and CS-LCs under hypoxic condition compared to normoxic conditions. The results showed that the $\mathrm{IC}_{50}$ of curcumin in MCF-7 cells was significantly higher in hypoxic conditions versus normoxic conditions ( $P \leq 0.05)$, while the $\mathrm{IC}_{50}$ of curcumin in CS-LCs was lower in hypoxic conditions compared to normoxic conditions although the difference was not statistically significant ( $>$ Fig. 2 ).

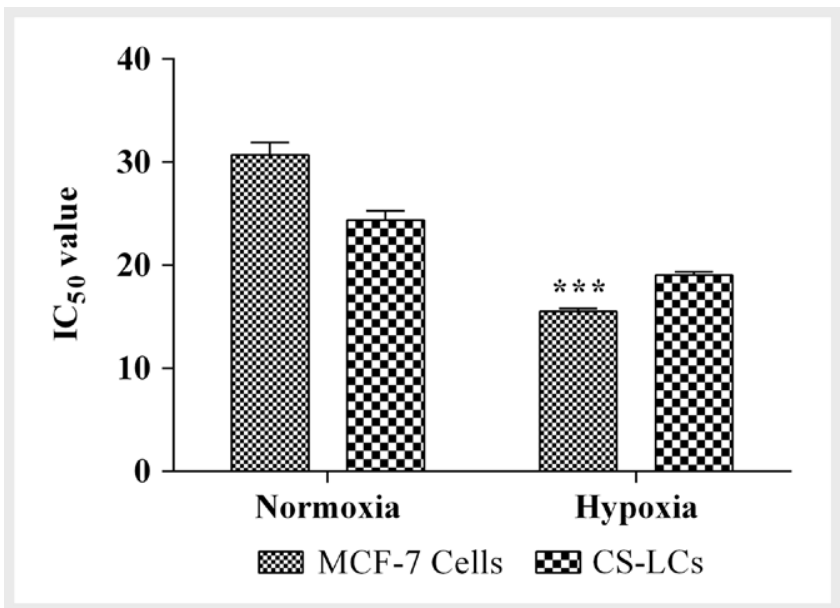

Fig. 2 Viability of CS-LCs and MCF-7 cells was evaluated using MTT assay after treatment with different concentrations of curcumin after $24 \mathrm{~h}$ under normoxic and hypoxic conditions (mean $\pm \mathrm{SD}, \mathrm{N}=9$ ). Comparison of $\mathrm{IC}_{50}$ value of MCF-7 cells and CS-LCs in normoxic (30.7 \pm 1.2 and $24.4 \pm 0.9 \mu \mathrm{M}$, respectively) and hypoxic conditions $(15.5 \pm 0.3$ and $19.05 \pm 0.3 \mu \mathrm{M}$, respectively) (mean \pm SD) showed that MCF-7 cells were more sensitive in hypoxic conditions compared to normoxic conditions $* * *(p \leq 0.001)$.

\section{The effects of Curcumin on CS-LCs and MCF-7 cells apoptosis}

We examined whether the toxic effect of curcumin on CS-LCs and MCF-7 cells was due to the induction of apoptosis. Annexin-V-FITC/ $\mathrm{PI}$ staining was performed to determine the percentage of apoptotic cells. CSC-LCs and MCF-7 cells were exposed to IC ${ }_{50}$ concentration of curcumin under normoxic and hypoxic conditions. According to the findings, \%) under hypoxic conditions, curcumin induced more apoptosis in CS-LCs (45.9\%) compared to MCF-7 cells (24.6). No statistical difference was observed in apoptosis between CS-LCs and MCF-7 cells under normoxic conditions ( $>$ Fig. $\mathbf{3}$, - Table 2) whereas in early apoptosis increased significantly in CSLCs compared to MCF-7 cells hypoxic conditions ( $P \leq 0.05)$.

\section{Effects of Curcumin on cell cycles of CS-LCs and MCF-7 cells}

To evaluate the inhibitory effects of curcumin on cell cycle phases of CS-LCs and MCF-7 cells in hypoxic and normoxic conditions, cell cycle analysis was performed using fluorescent PI-stained cellular DNA. CS-LCs and MCF-7 cells were exposed to $\mathrm{IC}_{50}$ concentration of curcumin and cell cycle distribution was determined via flow cytometry.

- Table 2 Effects of Curcumin on apoptosis of CSC-LC and MCF-7 under both normoxic and hypoxic conditions. Results are expressed as mean \pm SD, $\mathrm{N}=2$.

\begin{tabular}{|l|l|l|l|}
\hline & Live cells & $\begin{array}{l}\text { Early } \\
\text { apoptosis }\end{array}$ & $\begin{array}{l}\text { Late } \\
\text { apoptosis }\end{array}$ \\
\hline Normoxia & & & \\
\hline CSC-LC & $45.12 \pm 4.2$ & $46.31 \pm 2.8$ & $3.92 \pm 0.3$ \\
\hline MCF-7 cells & $49.51 \pm 0.86$ & $55.3 \pm 2.6$ & $6.17 \pm 0.6$ \\
\hline Hypoxia & & & \\
\hline CSC-LC & $44.15 \pm 5.7$ & $45.9 \pm 3.2$ & $2.14 \pm 0.08$ \\
\hline MCF-7 cells & $60 \pm 1.5$ & $24.6 \pm 1.8$ & $5.05 \pm 1.09$ \\
\hline
\end{tabular}

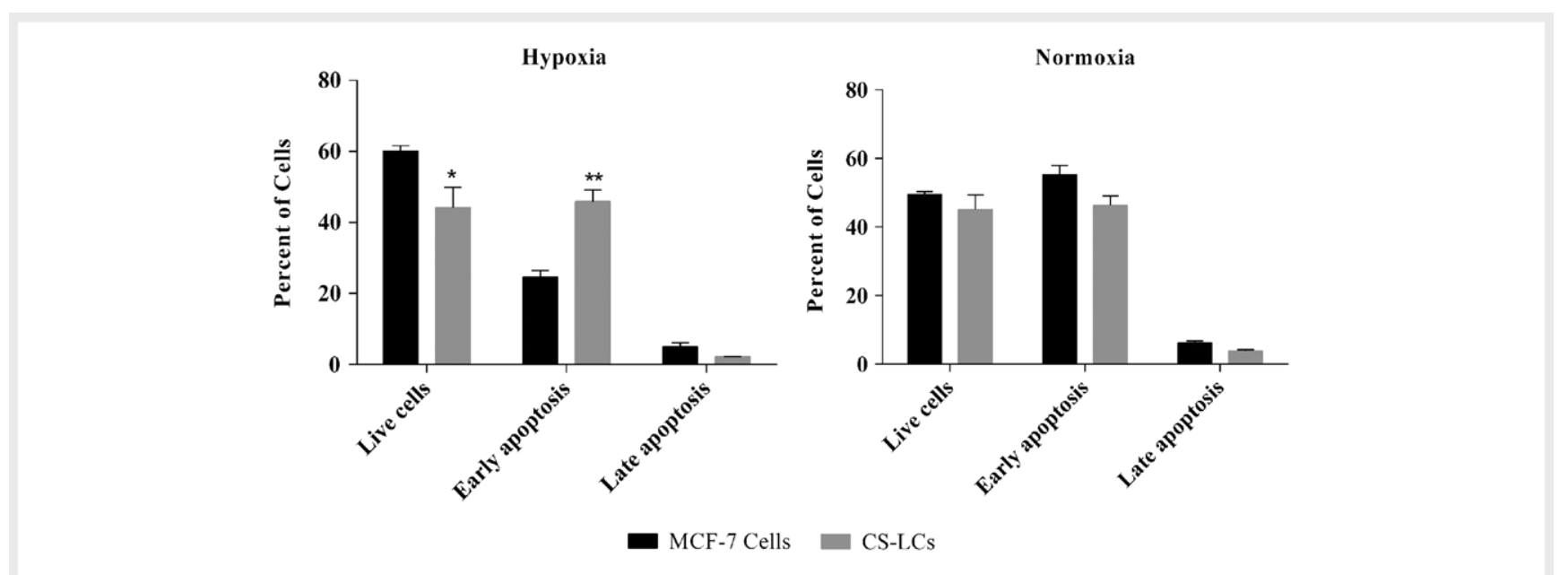

-Fig. 3 Effects of curcumin on apoptosis of CS-LCs and MCF-7 cells. a) No difference was observed in apoptosis between CSC-LCS and MCF-7 under normoxic condition. b) Early apoptosis occurred in CSC-LC (45.9\%) that was significantly increased under hypoxic conditions in comparison with the MCF- 7 cells $(24.6 \%),{ }^{*}(\mathrm{P}<0.05),{ }^{* *}(\mathrm{p}<0.01)$. 
- Table 3 Effects of Curcumin on CSC-LC and MCF-7 cells cycle under normoxic condition. Results are expressed as mean $\pm S D, N=2$.

\begin{tabular}{|l|l|l|l|}
\hline $\begin{array}{l}\text { Nor- } \\
\text { moxia }\end{array}$ & G0/G1 & S & G2/M \\
\hline MCF-7 & & & \\
\hline Control & $59.5 \% \pm 1.2$ & $25.05 \% \pm 2.8$ & $14.72 \% \pm 2.24$ \\
\hline $\begin{array}{l}30 \mu \mathrm{M} \\
\text { Curcumin }\end{array}$ & $68.24 \% \pm 2.9$ & $19.03 \% \pm 1.35$ & $5.26 \% \pm 1.7$ \\
\hline CSC-LC & & & \\
\hline Control & $55.2 \% \pm 2.1$ & $24.08 \% \pm 1.1$ & $18.05 \% \pm 1.9$ \\
\hline $\begin{array}{l}25 \mu \mathrm{M} \\
\text { Curcumin }\end{array}$ & $47.58 \% \pm 0.5$ & $29.6 \% \pm 1.8$ & $28.35 \% \pm 0.18$ \\
\hline
\end{tabular}

- Table 4 Curcumin effects on CSC-LC and MCF-7 cells cycle under hypoxic condition. CSC-LC and MCF-7 were treated with Curcumin at IC $\mathrm{C}_{50}$ concentration ( 25 and $30 \mu \mathrm{M}$ ) for normoxic concentration and also 19 and $15 \mu \mathrm{M}$ for hypoxic concentration. Flowjo software was used for data analysis. Results are expressed as mean $\pm \mathrm{SD}, \mathrm{N}=2$.

\begin{tabular}{|l|l|l|l|}
\hline Hypoxia & G0/G1 & S & G2/M \\
\hline MCF-7 & & & \\
\hline Control & $59.01 \% \pm 5.6$ & $36.14 \% \pm 5.5$ & $8.8 \% \pm 0.81$ \\
\hline $\begin{array}{l}16 \mu \mathrm{M} \\
\text { Curcumin }\end{array}$ & $60.59 \% \pm 2.4$ & $26.7 \% \pm 2.3$ & $13.25 \% \pm 1.5$ \\
\hline CSC-LC & & & \\
\hline Control & $61.5 \% \pm 2.5$ & $35.7 \% \pm 0.49$ & $6.39 \% \pm 0.06$ \\
\hline $\begin{array}{l}19 \mu \mathrm{M} \\
\text { Curcumin }\end{array}$ & $50.85 \% \pm 2.3$ & $27.37 \% \pm 2.1$ & $26.5 \% \pm 2.9$ \\
\hline
\end{tabular}

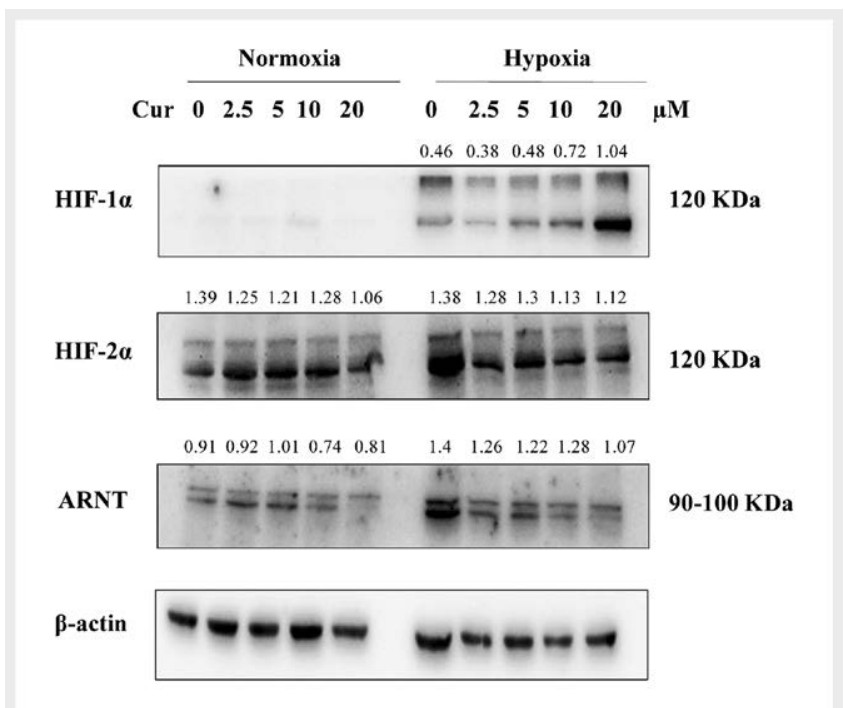

Fig. 4 Effects of curcumin on HIF-1 $\alpha$, ARNT, and HIF-2 $\alpha$ protein expression in CS-LCs using western blot as explained in Materials and Methods section. CS-LCs were treated with up to $20 \mu \mathrm{M}$ of curcumin for $24 \mathrm{~h}$ under hypoxic and normoxic conditions. Curcumin reduced the levels of ARNT and HIF-2 $\alpha$ protein in both normoxic and hypoxic conditions in a dose dependent manner.
As shown in $>$ Table 3, curcumin caused an increase in the G0/ G1 phase ( $59.5 \%$ vs. $68.24 \%$ ) in normoxic conditions; by contrast, $\mathrm{S}$ and $\mathrm{G} 2 / \mathrm{M}$ phases were decreased in MCF-7 cells. Furthermore, treatment of CSC-LC with curcumin led to a rise in the $\mathrm{S}(24.08 \%$ vs. $29.64 \%$ ) and $\mathrm{G} 2 / \mathrm{M}$ phases (18.05\% vs. $28.35 \%$ ) in comparison to the control group ( $\triangleright$ Table 3 ). As shown in $\triangleright$ Table 4, there was a decrease in $\mathrm{GO} / \mathrm{G} 1$ and $\mathrm{S}$ phases and an increase in the $\mathrm{G} 2 / \mathrm{M}$ phase in both CS- LCs and MCF-7 cells under hypoxic condition.

\section{Effects of Curcumin on HIF-1 (HIF-1 $\alpha$, ARNT) and HIF- $2 \alpha$ expression}

The inhibitory effects of curcumin on HIF protein expression of CSLCs was investigated by western blotting. CS-LCs were treated with $2.5,5,10$, and $20 \mu \mathrm{M}$ of curcumin under normoxic and hypoxic conditions. The results indicated that curcumin reduced the levels of ARNT and HIF-2 $\alpha$ protein in both normoxic and hypoxic conditions in a dose dependent manner. However, the HIF-1 $\alpha$ level was not affected by curcumin under normoxic and hypoxic conditions ( $>$ Fig. 4).

\section{Discussion}

Breast cancer is the most prevalent malignancy in women with a higher mortality rate among all cancers. Despite treatment developments, tumor recurrence and therefore decreased survival are common problems. Researchers have recently focused on new agents with cytotoxic effect on cancer cells, especially CSCs. Therefore, this study was conducted to examine the effect of curcumin on MCF-7 cells and CSC-LCs in hypoxic and normoxic conditions. It has been shown that tumor heterogeneity is one of the reasons for treatment failure resulting in disease recurrence. Recent studies have indicated that existing CSCs in solid tumors lead to chemotherapy resistance; therefore, CSCs should be eliminated to overcome drug resistance [15]. CSCs are a limited subpopulation with specific properties like self-renewal that are detected in several malignancies such as melanoma, breast, prostate and colon [16, 17]. Several studies have focused on isolating CSCs according to surface markers in order to develop new anticancer agents for targeted chemotherapy $[17,18]$. Moreover, the $\mathrm{CD}_{44}{ }^{+} / \mathrm{CD}_{24}{ }^{-}$phenotype has been proven for isolating the population of cells with CSCs properties from breast cancer cell lines (MCF-7 and MDA-MB 231 cells) [19]. In this study, CS- LCs were isolated from MCF-7 cells using the MACS method and characterized via flow cytometry. In MCF-7 cells, $0.78 \%$ of the population expressed the $\mathrm{CD}_{44}{ }^{+} / \mathrm{CD}_{24}$ - phenotype; however, this phenotype increased markedly to $33.86 \%$ after MACS sorting.

Curcumin has different therapeutic effects such as antioxidant, anti-inflammatory, and antitumor properties [13, 20]. In addition, several studies found that curcumin had negligible toxicity and adverse effects. Therefore, in recent years, curcumin has received significant attention in clinical trials as an antitumor agent in different cancers [21,22]. Furthermore, the combination of curcumin with other chemotherapeutic agents may increase the efficacy of treatment and inhibition of cancer cell growth $[9,23]$. Liu et al. found that curcumin decreased cell viability and induced apoptosis in ovarian cancer cell lines [22]. The present study showed that curcumin was more toxic for MCF-7 cells in hypoxic conditions ( $\mathrm{IC}_{50}$, $15.5 \mu \mathrm{M})$ compared to normoxic conditions ( $\left.\mathrm{IC}_{50}, 30.7 \mu \mathrm{M}\right)$; be- 
sides, the inhibitory effect of curcumin on cell viability of CS- LCs was increased in hypoxic conditions but it was not significant.

Curcumin can induce apoptosis in various cancer cells via upregulation of proapoptotic genes including caspase cascades, BAX, and PUMA and downregulation of antiapoptotic genes such as BCL2 $[24,25]$. Annexin- $V$ and PI staining was done to evaluate the antiproliferative property of curcumin in MCF-7 cells and CS-LCs under hypoxic and normoxic conditions. The results showed that apoptosis occurred in $\mathrm{IC}_{50}$ concentration of curcumin in MCF-7 cells and CS- LCs under normoxic and hypoxic conditions, whereas curcumin-induced apoptosis was significantly more in CS-LCs compared to MCF-7 cells under hypoxic conditions.

Flow cytometry was used to determine the mechanism of the growth inhibitory effect of curcumin on cell proliferation. The results of the cell cycle showed curcumin in $\mathrm{IC}_{50}$ concentration induced arrest in MCF-7 cells and CS-LCs in the G2/M phase in hypoxic conditions. By contrast, in normoxic conditions, curcumin induced G0/G1 arrest in MCF-7 cells at a concentration of $30.7 \mu \mathrm{M}$ and $\mathrm{G} 2 / \mathrm{M}$ and S cell cycle arrest in CS- LCs at a concentration of $24.4 \mu \mathrm{M}$. It has been demonstrated that curcumin could induce $\mathrm{G} 2$ / $M$ arrest in melanoma cells [26].

Next, the inhibitory effect of curcumin on HIFs expression was assessed in MCF-7 cells and CS-LCs under hypoxic and normoxic conditions. Recent studies have demonstrated that hypoxia leads to the survival of CSCs in tumors by overexpression of HIFs resulting in resistance to chemotherapy and tumor recurrence. Furthermore, the activity of HIFs has a pivotal role in tumor progression, angiogenesis, invasion and metastasis; therefore, they play a crucial role in the survival of tumor cells in hypoxic Conditions [27, 28]. Several studies have focused on developing anticancer agents by targeting HIF1 subunits and HIF $2 \alpha$ [29]. Ströfer et al. investigated the inhibitory effect of curcumin on HIF1 subunits and HIF2 $\alpha$ protein levels in MCF-7 cells under hypoxic and normoxic conditions [30]. The results of the present study showed that treatment of CSLCs with curcumin did not inhibit the levels of HIF- $1 \alpha$ protein expression. Moreover, curcumin had an inhibitory effect on ARNT and HIF $2 \alpha$ protein expression in CS-LCs at a concentration of $20 \mu \mathrm{M}$ under hypoxic and normoxic conditions. Therefore, curcumin as an antitumor herbal composition could inactivate HIF-1 by degrading ARNT and decreasing the level of HIF $2 \alpha$ protein in CS-LCs under normoxic and hypoxic conditions. Thus, the results suggest that curcumin can be used as an antitumor compound due to inhibiting the ARNT and HIF $2 \alpha$ protein expression in CS-LCs, which may inhibit tumor metastasis.

\section{Conclusion}

In conclusion, this study found that curcumin had cytotoxic effects on CS-LCs and MCF-7 cells under normoxic and hypoxic conditions. Based on these findings, curcumin can be considered as an antitumor agent that affects CSCs and breast cancer cells.

\section{Funding}

This project was supported by grant number 93-04-33-27666 from Deputy of Research Tehran University of Medical Sciences.

\section{Declaration of Conflicting Interests}

The authors declare no potential conflicts of interest.

\section{References}

[1] Parks R, Derks M, Bastiaannet E et al. Breast cancer epidemiology. Breast Cancer Management for Surgeons. Springer; 2018: 19-29

[2] DeSantis C, Howlader N, Cronin KA et al. Breast cancer incidence rates in US women are no longer declining. Cancer Epidem Biomar 2011; 20: 733-739

[3] Wahba HA, El-Hadaad HA. Current approaches in treatment of triple-negative breast cancer. Cancer Biol Med 2015; 12: 106

[4] García-Aranda M, Redondo M. Immunotherapy: A Challenge of Breast Cancer Treatment. Cancers 2019; 11: 1822

[5] Boo L, Ho WY, Ali NM et al. MiRNA transcriptome profiling of spheroid-enriched cells with cancer stem cell properties in human breast MCF-7 cell line. Int J Biol Sci 2016; 12: 427

[6] Turdo A, Veschi V, Gaggianesi M et al. Meeting the challenge of targeting cancer stem cells. Front Cell Dev Biol 2019; 7: 16

[7] Smith AG, Macleod KF. Autophagy, cancer stem cells and drug resistance. J Pathol 2019; 247: 708-718

[8] Meacham CE, Morrison S]. Tumour heterogeneity and cancer cell plasticity. Nature 2013; 501: 328-337

[9] Sankpal UT, Nagaraju GP, Gottipolu SR et al. Combination of tolfenamic acid and curcumin induces colon cancer cell growth inhibition through modulating specific transcription factors and reactive oxygen species. Oncotarget 2016; 7: 3186

[10] Li W, Ma H, Zhang J et al. Unraveling the roles of CD44/CD24 and ALDH1 as cancer stem cell markers in tumorigenesis and metastasis. Sci Rep 2017; 7: 13856

[11] Choi H, Chun Y-S, Kim T-Y et al. HIF-2 $\alpha$ enhances $\beta$-catenin/TCF-driven transcription by interacting with $\beta$-catenin. Cancer Res 2010; 70: 10101-10111

[12] Yu T, Tang B, Sun X. Development of inhibitors targeting hypoxiainducible factor 1 and 2 for cancer therapy. Yonsei Med J 2017; 58: 489-496

[13] Kocaadam B, Şanlier N. Curcumin, an active component of turmeric (Curcuma longa), and its effects on health. Crit Rev Food Sci Nutr 2017; 57: 2889-2895

[14] Shadboorestan A, Tarfiei GA, Montazeri $\mathrm{H}$ et al. Invasion and migration of MDA-MB-231 cells are inhibited by block of AhR and NFAT: role of AhR/NFAT1/B4 integrin signaling. J Appl Toxicol 2019; 39: 375-384

[15] Phi LTH, Sari IN, Yang Y-G, et al. Cancer stem cells (CSCs) in drug resistance and their therapeutic implications in cancer treatment. Stem Cells Int 2018; 2018: 5416923

[16] Ki J, Shim Y, Song JM. High-content cell death imaging using quantum dot-based TIRF microscopy for the determination of anticancer activity against breast cancer stem cell. J Biophotonics 2017; 10: 118-127

[17] Sajadian S, Vatankhah M, Majdzadeh M et al. Cell cycle arrest and apoptogenic properties of opium alkaloids noscapine and papaverine on breast cancer stem cells. Toxicol Mech Method 2015; 25: 388-395

[18] Cui ], Hollmén M, Li L et al. New use of an old drug: inhibition of breast cancer stem cells by benztropine mesylate. Oncotarget 2017; 8: 1007

[19] Wang L, He Y, Wu L et al. Isolation and characterization of human breast tumor stem cells. Xi Bao Yu Fen Zi Mian Yi Xue Za Zhi 2012; 28 : 1261-1264

[20] Hatcher H, Planalp R, Cho J et al. Curcumin: from ancient medicine to current clinical trials. Cell Mol Life Sci 2008; 65: 1631-1652 
[21] Dhillon N, Wolff R, Abbruzzese ] et al. Phase II clinical trial of curcumin in patients with advanced pancreatic cancer. J Clin Oncol 2006; 24: 14151-14151

[22] Liu L-d, Pang Y-x, Zhao X-r et al. Curcumin induces apoptotic cell death and protective autophagy by inhibiting AKT/mTOR/p70S6K pathway in human ovarian cancer cells. Arch Gynecol Obstet 2019; 299: $1627-1639$

[23] Anitha A, Deepa N, Chennazhi K et al. Combinatorial anticancer effects of curcumin and 5-fluorouracil loaded thiolated chitosan nanoparticles towards colon cancer treatment. Biochim Biophys Acta 2014; 1840: $2730-2743$

[24] Zhu Y, Bu S Curcumin induces autophagy, apoptosis, and cell cycle arrest in human pancreatic cancer cells. Evid Based Complement Alternat Med 2017; 2017: 5787218

[25] Shankar S, Srivastava RK. Involvement of Bcl-2 family members, phosphatidylinositol 3'-kinase/AKT and mitochondrial p53 in curcumin (diferulolylmethane)-induced apoptosis in prostate cancer. Int J Oncol 2007; 30: 905-918
[26] Zhao G, Han X, Zheng S et al. Curcumin induces autophagy, inhibits proliferation and invasion by downregulating AKT/mTOR signaling pathway in human melanoma cells. Oncol Rep 2016; 35: 1065-1074

[27] Harris AL. Hypoxia - a key regulatory factor in tumour growth. Nat Rev Cancer 2002; 2: 38

[28] Anderson TMR, Peacock DL, Daniel AR et al. Breast tumor kinase (Brk/ PTK6) is a mediator of hypoxia-associated breast cancer progression. Cancer Res 2013; 73: 5810-5820

[29] Xing $Y, M i ~ C$, Wang $Z$ et al. Fraxinellone has anticancer activity in vivo by inhibiting programmed cell death-ligand 1 expression by reducing hypoxia-inducible factor- $1 \alpha$ and STAT3. Pharmacol Res 2018; 135 : $166-180$

[30] Ströfer M, Jelkmann W, Depping R. Curcumin decreases survival of Hep3B liver and MCF-7 breast cancer cells. Strahlenther Onkol 2011; 187: $393-400$ 